\title{
Legal Implications for Actions Considered Iatrogenic: Knowledge and Practices of the Surgical Team, Valledupar, Cesar/Colombia
}

\author{
Anderson Díaz-Pérez ${ }^{1,2}$. Yeison Jair Guerra Peralta ${ }^{1}$. Helen Morón Montero ${ }^{1}$. Claudia Pacheco Castaño ${ }^{1}$ \\ Breiner Vergara Acosta ${ }^{1} \&$ Tahania Chona Rodriguez ${ }^{1}$ \\ ${ }^{1}$ Faculty of Health Sciences, Surgical Instrumentation Program, Universidad Popular Del Cesar, Valledupar, \\ Colombia \\ ${ }^{2}$ Universidad Simón Bolívar, Department of Social and Human Sciences, Barranquilla, Colombia. \\ Correspondence: Anderson Díaz Pérez, Faculty of Health Sciences, Surgical Instrumentation Program, Universidad \\ Popular Del Cesar, Valledupar, Colombia. ORCID id: https://orcid.org/0000-0003-2448-0953 E-mail: \\ ander2711@gmail.com
}

Received: November 3, 2019 Accepted: January 9, 2020 Online Published: January 30, 2020

doi:10.5539/gjhs.v12n2p90

URL: https://doi.org/10.5539/gjhs.v12n2p90

\begin{abstract}
Introduction: The errors considered iatrogenic are caused by different causes that are mostly considered foreseeable, including inaccuracy, recklessness and ignorance, all these actions with ethical-legal repercussions. In Colombia, despite not having studies that position iatrogeny as one of the main causes of death. It is estimated that in Colombia 180,000 people die each year for this reason. Iatrogeny is described in the USA as the third leading cause of death. Objective: To evaluate the knowledge and aspects related to negligence, inexperience, recklessness, that the surgical team has in regard to its ethical-legal responsibilities.

Methodology: Descriptive cross-sectional study. A total of 93 professionals were surveyed who are part of the surgical team of two health-care institutions in the department of Cesar, Colombia during 2019.

Results: Surveyed professionals showed a $100 \%$ ignorance about the process to follow during an adverse event. It was identified that $32 \%$ of the professionals and technicians surveyed do not have insurance to back them up legally. In addition, $31 \%$ said that errors such as negligence, recklessness and inexperience can occur in parallel with criminal and civil repercussions. The surgical team considers that the most frequent error are elements and instruments left in the cavity (oblites) in 64\%.
\end{abstract}

Conclusions: For surgical personnel, negligence is the error with the greatest penal repercussion if it is related to the death of the patient, surgery on the wrong patient and wrong side of the body, in addition to oblites or foreign bodies left in the cavity.

Keywords: iatrogeny, negligence, recklessness, ethical aspects, legal aspects, liability, medical malpractice.

\section{Introduction}

A medical action can be beneficial, iniquitous or harmful. Iatrogenesis is any damage caused on the body or in the health of the patient by the physician through his actions, behaviors at the time of diagnosis, therapy, surgical procedure, among others. That is to say, iatrogeny is the harmful result that does not derive from the will of the doctor in the production of damage, but is the product of an unforeseen event that escapes any possibility of being avoided by the doctors (Millenson, 2018; Silversides, 2008; Vera Carrasco, 2013).

Actions considered iatrogenic are caused by different human factors, as well as by the lack of foresight, protocols and regulations, that is, those considered by the system. These elements lead to actions considered as medical errors (medical negligence). Medical negligence considered as the total or partial lack of technical knowledge, experience or skill, that is, as the ineptitude of professional performance. Recklessness is reflected in the damage caused because the medical action was performed without proper precautions or without measuring the consequences (Vera Carrasco, 2013).

Iatrogenic damage can be of three types: predictable or calculated, random or accidental, and due to negligence or 
ineptitude. Predictable or calculated are inseparable from a primary effect, as in the case of medication administration, catheter placement, and so on. Random or accidental: May also occur with the administration of medications, but exceptionally. Negligence: Due to Ineptitude or Inability. (Dewees, Trebilcock, \& Coyte, 1991; Perez, 2019; Silversides, 2008; Studdert, Brennan, \& Thomas, 1999; Tempelaar, 1997; Tingle, 2016).

In Colombia, although there are no studies that classify iatrogeny as one of the main causes of death, the rates are still alarming. In Colombia, it is estimated that 180,000 people die each year from iatrogeny, in which the legal truth lurks and taints medical practice, in which the vast majority of errors are not justified and cannot be allowed to occur. It is for this reason that their actions are delimited or typified as malpractice either by negligence, imprudence, inexperience or ignorance with the deontological and legal responsibilities that this entails according to the severity of the injury due to the error committed (Pérez, 2019; Guzmán Mora, 2018; Vera Carrasco, 2013; Ruiz, 2011; López Ordoñez, Manrique Bacca, \& García Torres, 2004; Guzmán, Franco, Morales, \& Mendoza, 1994).

In Colombia, the lawsuits against doctors are increasing at an alarming rate, with $75 \%$ of the processes occurring in the last three years. One might even think that the greater the experience, the less probability of error or iatrogeny, but the opposite is observed in which doctors with experience of even 9 years are in the first place of lawsuits and that the second position is occupied by doctors with experience of up to 15 years, the specialties with more lawsuits are: Gynecology, general surgery and anesthesiology (López Ordoñez et al., 2004). This same study mentions that the most predominant processes are: The penal ones, followed by the ethical and civil ones, although it can originate that all the processes are activated simultaneously, without forgetting that a process can begin up to 20 years after the attention, whereas the levels of complexity more compromised in processes of medical responsibility are the II and III respectively (López Ordoñez et al., 2004). In the United States 40\% of physicians are involved in responsibility processes during their professional practice as described by Daley J. Harrington J., cited by (López Ordoñez et al., 2004), but the actual national data on the rate of claims paid on behalf of U.S. physicians by specialty is still unknown (Schaffer et al., 2017)

In Colombia, the most frequent sanctions are those applied for violation of Law 23 of 1981 on medical ethics, which includes issues such as dedication of sufficient time to the patient, the quality of the medical history and submission to unjustified risks in which while it is true that to err is human, it is also the fact of adopting measures and precautions so that mistakes do not occur in which the principle of non-maleficence is applied from the Hippocratic oath of Primum Non Nocere: above all, do no harm! (Smith, 2005)

\subsection{Objective}

To evaluate the knowledge and aspects related to omission, negligence, recklessness and ignorance that the surgical team has regarding its responsibilities in actions considered as iatrogenic from an ethical and legal point of view.

\section{Methods}

Descriptive cross-sectional study. The population of professionals working as members of the surgical team in the area of surgery of two institutions that provide health services of third level of complexity was taken, for a total of 93 people, including anesthesiologists, surgeons, doctors, nurses and surgical instrumentalists. The study took place in the department of Cesar, Colombia 2019. Data were collected through the use of a dichotomous questionnaire format. The instrument was validated by experts (doctors and lawyers specialized in medical law). Two pilot tests were carried out to clarify several concepts related to medical malpractice and actions that are considered iatrogenic, these elements helped to define the reliability of the instrument applied. Data are presented in terms of frequency and percentage. The respective informed consent was applied to each of the members of the surgical team, as well as the respective permits requested from the health institutions (ethics and research committees), as well as the approval of the ethics and research committee of the Program of Surgical Instrumentation of the Popular University of Cesar, Valledupar-Colombia. The project complies with the principle of confidentiality as stipulated in the Declaration of Helsinki.

\section{Results}

The general population consisted of 93 professionals, which is represented by surgeons $30 \%, 27 \%$ are surgical assistants, $22 \%$ are auxiliary nurses, $11 \%$ assistant doctor, $9 \%$ anesthesiologists and $2 \%$ professional nurses. In relation to the 28 specialists analyzed, $32 \%$ are gynecologists, $29 \%$ are general surgeons and $11 \%$ are orthopedic surgeons, plastic surgeons and neurosurgeons represent each group $7 \%$, pediatricians, urologists, otolaryngologists and cardiovascular surgeons represent each group $4 \%$. The highest frequency age range was from 30 to 39 corresponding to $34 \%$. Of the 93 professionals, $53 \%$ have from 0 to 10 years of experience in surgery, $27 \%$ have from 
11 to 20 years of experience in surgery, $19 \%$ have from 21 to 40 years of experience in surgery and $1 \%$ have from 40 to 50 years of experience. It is important to note that only $68 \%$ mention being insured on ethical and legal aspects. (See table 1).

The majority of professionals consider that general and gynecological surgeries are the areas in which iatrogenic surgeries are most likely to occur, $60 \%$ have witnessed or heard of surgical errors, $33 \%$ have not witnessed or heard of surgical errors, $6 \%$ decided not to answer this question. Professionals describe that the most witnessed or heard error is that of a foreign body forgotten inside the patient's body and the least witnessed or heard is that of performing a surgical procedure on the wrong patient, which is detailed below: $64 \%$ witnessed or heard from a foreign body, $13 \%$ from a human error, $11 \%$ from a wrong procedure, $9 \%$ from an organ lesion, and $4 \%$ from a wrong patient. It is highlighted that $55 \%$ consider the factors that have a significant influence on the occurrence of errors are the following: absence of protocol in $28 \%, 12 \%$ related to the person, $4 \%$ consider it to be due to lack of means and infrastructure and $1 \%$ consider it to be another type of factor, but do not specify which one. The specialists typify the cause of the error in $29 \%$ by negligence, $26 \%$ by imprudence, $4 \%$ by inexperience, $4 \%$ did not answer the question, $1 \%$ consider that it is another cause of medical error during surgery. However, $35 \%$ consider that all the options are the cause for the occurrence of medical error during the surgical procedure (See Tables 2 and 3).

On the other hand, when professionals describe the liability to which they project the error, they describe negligence with a civil repercussion as the one with the greatest liability. However, it should be noted that in a similar percentage all the errors described have civil repercussions. Professionals mention that their responsibility in the event of the death of a patient due to medical error may be of a penal nature, and that in the case of which the incident is proven, the health professional could also end up involved in other types of responsibilities such as civil, administrative, deontological, among others. Regarding the process that the professional should follow when reporting an error, $97 \%$ selected the wrong order and 3\% did not answer the question. (See Table 4). 
Table 1. Characteristics of the analyzed population related to professional aspects and legal protection

\begin{tabular}{|c|c|c|c|c|c|c|c|c|c|c|c|}
\hline \multirow{3}{*}{$\begin{array}{l}\text { Surgical specialty } \\
\text { Gynecological Surgery }\end{array}$} & \multirow{3}{*}{$\begin{array}{l}\text { n (\%) } \\
9(32)\end{array}$} & \multicolumn{2}{|c|}{$\begin{array}{l}\text { Health-care } \\
\text { institutions }\end{array}$} & \multicolumn{2}{|l|}{ Occupation } & \multicolumn{2}{|l|}{ Age range } & \multicolumn{2}{|c|}{$\begin{array}{l}\text { Years of experience in } \\
\text { the surgical service }\end{array}$} & \multicolumn{2}{|c|}{$\begin{array}{l}\text { Protection it } \\
\text { ethical-legal aspects }\end{array}$} \\
\hline & & Dublic & $\mathrm{n}(\%)$ & Suroron & n (\%) & 2120 & $\mathrm{n}(\%)$ & $0-10$ vears & n (\%) & Yes & n (\%) \\
\hline & & 1 tuonti & $57(61)$ & Sulgeoil & $28(30)$ & $21-29$ & $20(22)$ & -10 yeals & $49(53)$ & res & $63(68)$ \\
\hline Pediatric Surgery & $1(4)$ & Private & $36(39)$ & Medical Assistant & $10(11)$ & $30-39$ & $32(34)$ & $11-20$ years & $25(27)$ & No & $30(32)$ \\
\hline General Surgery & $8(29)$ & Other & $0(0,00)$ & Surgical assistants & $25(27)$ & $40-49$ & $14(15)$ & $21-40$ years & $18(19)$ & Total & $93(100)$ \\
\hline Urological Surgery & $1(4)$ & Total & $93(100)$ & Auxiliary Nurse & $20(22)$ & $50-59$ & $13(14)$ & $40-50$ years & $1(1)$ & & \\
\hline Otorhinolaryngology & $1(4)$ & & & Nurse & $2(2)$ & $60-69$ & $7(8)$ & Total & $93(100)$ & & \\
\hline Plastic Surgery & $2(7)$ & & & Anesthesiologist & $8(9)$ & 70 & $2(2)$ & & & & \\
\hline Cardiovascular Surgery & $1(4)$ & & & Total & $93(100)$ & Dnk/Dna & $5(5)$ & & & & \\
\hline Neurosurgery & $2(7)$ & & & & & Total & $93(100)$ & & & & \\
\hline Orthopedic Surgery & $3(11)$ & & & & & & & & & & \\
\hline Total & $28(100)$ & & & & & & & & & & \\
\hline
\end{tabular}

n: Frequency. \%: Percentage. Dnk/Dna: Does not know - Does not answer

Table 2. Knowledge and perceptions of the surgical team related to the responsibility and frequency of cases with ethical-legal responsibility.

\begin{tabular}{|c|c|c|c|c|c|c|c|}
\hline \multicolumn{2}{|c|}{$\begin{array}{l}\text { Perception of the surgical team in relation to the frequency of } \\
\text { errors by specialty }\end{array}$} & \multicolumn{2}{|c|}{$\begin{array}{l}\text { Knowledge of iatrogenic } \\
\text { cases }\end{array}$} & \multicolumn{2}{|c|}{$\begin{array}{l}\text { Knowledge of civil liability for } \\
\text { medical error }\end{array}$} & \multicolumn{2}{|c|}{ Knowledge of legal liability for medical error } \\
\hline \multirow{2}{*}{ Gynecology } & $\mathrm{n}(\%)$ & \multirow{2}{*}{ Yes } & $\mathrm{n}(\%)$ & \multirow{2}{*}{ Due to Negligence } & $\mathrm{n}(\%)$ & \multirow{2}{*}{ Due to Negligence } & $\mathrm{n}(\%)$ \\
\hline & $28(30)$ & & $56(60)$ & & $33(35)$ & & $34(37)$ \\
\hline General Surgery & $31(33)$ & No & $31(33)$ & Because of Recklessness & $11(12)$ & Because of Recklessness & $2(2)$ \\
\hline Neurosurgery & $3(3)$ & Dnk/Dna & $6(6)$ & Due to Imperiousness & $7(8)$ & Due to Imperiousness & $1(1)$ \\
\hline Reconstructive Plastic Surgery & $3(3)$ & Total & $93(100)$ & By Ignorance & $8(9)$ & By Ignorance & $8(9)$ \\
\hline Orthopedy & $3(3)$ & & & All of the Above & $29(31)$ & All of the Above & $46(49)$ \\
\hline All specialties & $14(15)$ & & & Dnk/Dna & $5(5)$ & Dnk/Dna & $2(2)$ \\
\hline Dnk/Dna & $11(12)$ & & & Total & $93(100)$ & Total & $\begin{array}{l}93 \\
(100)\end{array}$ \\
\hline Total & $93(100)$ & & & & & & \\
\hline
\end{tabular}

n: Frequency. \%: Percentage. Dnk/Dna: Does not know - Does not answer. 
Table 3. Perceptions of evidenced errors, latent or active factors and classification of the error

\begin{tabular}{|c|c|c|c|c|c|}
\hline \multicolumn{2}{|l|}{ Type of identified error } & \multicolumn{2}{|l|}{ Factors Influencing Medical Errors } & \multicolumn{2}{|c|}{ Causes of medical error in surgery } \\
\hline \multirow{2}{*}{ Wrong Procedure } & $\mathrm{n}(\%)$ & \multirow{2}{*}{ The person } & $\mathrm{n}(\%)$ & \multirow{2}{*}{ Due to Negligence } & $\mathrm{n}(\%)$ \\
\hline & $6(11)$ & & $11(12)$ & & $27(29)$ \\
\hline Wrong Patient & $2(4)$ & Lack of protocols and procedures & $26(28)$ & Because of Recklessness & $24(26)$ \\
\hline Foreign object & $36(64)$ & Lack of resources and infrastructure & $4(4)$ & Due to Imperiousness & $4(4)$ \\
\hline Organ lesion & $5(9)$ & All of the above & $51(55)$ & By Ignorance & $1(1)$ \\
\hline Human Error & $7(13)$ & Other & $1(1)$ & All of the Above & $33(35)$ \\
\hline Total & $56(100)$ & Total & $93(100)$ & Dnk/Dna & $4(4)$ \\
\hline
\end{tabular}

n: Frequency. \%: Percentage. Dnk/Dna: Does not know - Does not answer.

Table 4. Types of ethical-legal responsibility and procedure for failure or error by the surgical team

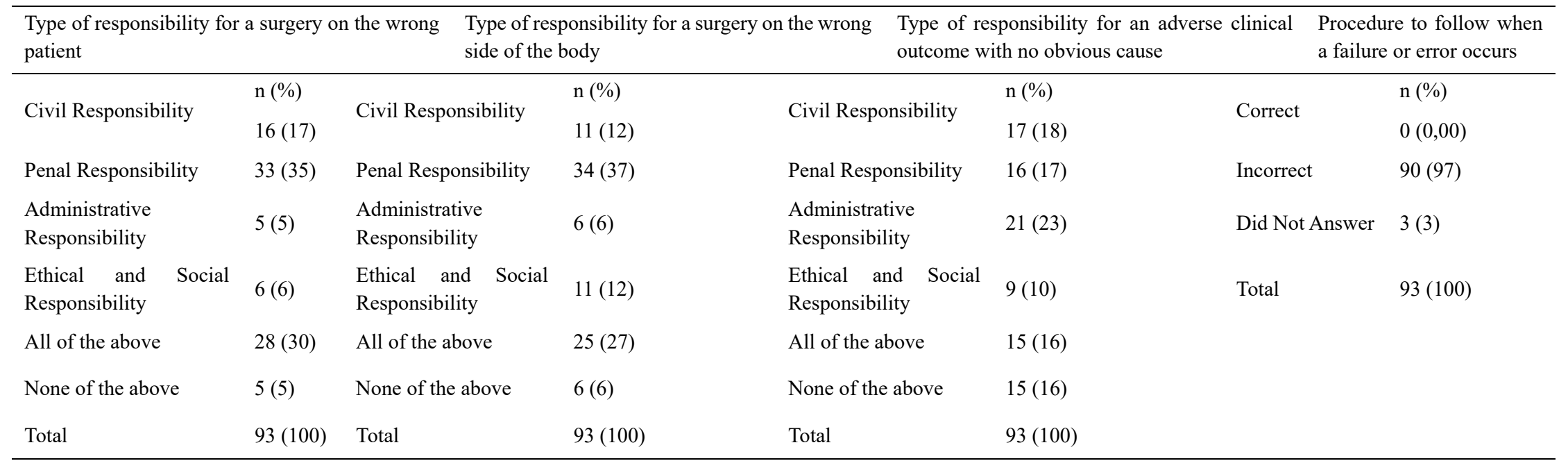

n: Frequency. \%: Percentage. Dnk/Dna: Does not know - Does not answer. 


\section{Discussion and Conclusions}

The results show that the factors perceived by the surgical team that influence the presence of iatrogenesis is the lack of protocols and processes, which is contrasted with the results and analyses of other studies such as those reported by (López Ordoñez et al., 2004; Ruiz, 2011; Studdert et al., 1999; Tempelaar, 1997).

When we analyzed the causes of medical error in surgery it was observed that the typification of the most frequent errors according to the perception of the surgical team are errors due to negligence and recklessness as it is also described by authors as (Schaffer et al., 2017; Tingle, 2016; López Ordoñez et al., 2004; Tempelaar, 1997; Dewees et al., 1991). Even these authors propose the paradox that the greater the clinical experience, the greater the probability of making mistakes, perhaps due to overconfidence, which increases the impact of lawsuits on hospital costs (Pérez, 2019; Tingle, 2016; López Ordoñez et al., 2004).

Medical liability is the ability of a health care professional to accept his or her commitment to an adverse event in which the objective duty of care has been breached and in which negligence, inexperience, recklessness or failure to comply with regulations has been demonstrated (Guzmán Mora, 2018; Ruiz, 2011; Smith, 2005; Guzmán et al., 1994). Medical errors due to malpractice are closely linked to penal responsibility, which is regulated in Law 23 of 1981 and its Regulatory Decree 3380 of 1981 in Colombia, which determines the functions of the physician and his relationship with patients and society. With the incorporation of the Court of Medical Ethics "went from being a moral responsibility to a legal one, as the conduct was examined by a State Court through a legal procedure and with sanctions that produce external effects" because of all the dynamics of responsibility would lead the medical profession to be considered as a profession at risk (Guzmán Mora, 2018; Ávila Guevara, Cortes, Hernández, \& Vargas Oviedo, 2016; Ruiz, 2011; López Ordoñez et al., 2004; Guzmán et al., 1994). In other words, the search for medical responsibility seeks the best way to repair the harm done to the patient and his or her family in relation to the severity of the damages caused.

Concerning the analysis of the errors with the greatest penal impact, it is first clarified that in order to consider that an error is of penal responsibility, the following elements must be presented: An active or passive behavior (action) attributable to the doctor, whether in the form of malice or guilt, that represents harm to the patient and that establishes, among these, a causality nexus. Such behavior contradicts the principles of the medical profession. 3 . That this behavior is in contradiction with the legal system, it should be pointed out that not only with the penal norms, but that it should be carried out by analyzing the legal system as a whole. 4. That such anti-juridical behavior is reproachable to the doctor, through the evidence of the case.

The results of our study show that for surgical personnel negligence is the error with the greatest penal repercussion. However, other studies such as those presented by (Ruiz, 2011; Marcela, Helena, \& Eduardo, 2011; Bernate-Ochoa, 2010; López Ordoñez et al., 2004; Lascariz Jiménez, 2000; Kunsemuller, 1986; Guzmán, Franco, \& Morales, 1996) mention that the most frequent medical lawsuits according to the legal system information are caused by human factors that lead to malpractice, carelessness or recklessness with a criminal liability of a malicious or negligent nature (Marcela et al., 2011; Barreiro Ramos, Barreiro Peñaranda, Quesada Soto, Fernández Viera, \& Marrero Martín, 2005; Guzmán et al., 1994).

In regard to the type of liability for errors resulting in the death of the patient, inter-institutional violation, surgery on the wrong patient and the wrong side of the body, among others, are placed in criminal liability. The inter-institutional violation of the patient and adverse results expected to the expected one without evident cause will be placed in the administrative responsibility because it is the option that has more percentage in the current study.

In our study it was observed that for the surgical team the death of the patient, surgery on the wrong patient and surgery on the wrong side of the body, the liability can be of a penal type as contrasted with other studies that mention that liability is not only penal but also civil. Furthermore, our study presents that the probability of error increases according to years of experience, type of specialty, among other factors (Millenson, 2018; Tingle, 2016; Marcela et al., 2011; Silversides, 2008; López Ordoñez et al., 2004; Tempelaar, 1997; Dewees et al., 1991).

Regarding administrative responsibility, the study shows that for the surgical team, the inter-institutional violation of the patient and the adverse result to the one expected without apparent cause can lead to administrative responsibility. This information is in contrast to the results Restrepo Giraldo (2015), in which it is observed that the Contentious-Administrative jurisdiction is the one with the most medical lawsuits, with $55.9 \%$ of all cases (Restrepo, 2015).

With regard to the procedure to be followed once the iatrogeny or error has been committed, it is necessary to take into account that, although the responsibility of talking to patients and/or their families about these results 
generally lies on the treating physician, nurses are often also involved because they are "closer" to the patient. This conversation between doctors/nurses and patients and/or relatives when something "bad" has happened is what the Anglo-Saxon literature has called "disclosure" (Pérez, 2019; Anderson et al., 2019; Aguirre-Gas \& Vázquez-Estupiñán, 2006). In the United States, this dialogue is not only one of the best institutional practices, but also a requirement of the Joint Commission to grant or maintain accreditation to hospitals and therefore it must be considered within the rights of patients (Franco, 2006).

In our study $100 \%$ of the professionals analyzed do not know what to do when a mistake is made. This data can be associated with the results of other research carried out in Colombia in which the professionals do not know the process of reporting a medical error or adverse event (Bernal Moreno \& Botero Mejía, 2016; Marcela et al., 2011; Villota, 2009; Gaitán, 2008; Aguirre-Gas \& Vázquez-Estupiñán, 2006; Franco, 2006; López Ordoñez et al., 2004).

\section{Competing Interests Statement}

The authors declare that there are no competing or potential conflicts of interest.

\section{References}

Aguirre-Gas, H. G., \& Vázquez-Estupiñán, F. (2006). El error médico. Eventos adversos. Cirugía y Cirujanos, 74(6), 495-503.

Anderson, D.-P., Vargas, A. C., Fuentes, K. U., Ochoa, A. D. V., Nuñez, L. P. C., Orozco, M. I. G. C., \& Oñate, Z. R. (2019). Cancellation of Surgeries by the Patient, Doctor or Institution: An Approach to Legal Ethical Aspects. Global Journal of Health Science, 11(9), 34. https://doi.org/10.5539/gjhs.v11n9p34

Ávila Guevara, J. M., Cortes, L. D., Hernández, D. F., \& Vargas Oviedo, L. A. (2016). Impacto y costos generados por las principales demandas a profesionales de la salud.

Barreiro Ramos, H., Barreiro Peñaranda, A., Quesada Soto, Z., Fernández Viera, E., \& Marrero Martín, O. (2005). La responsabilidad profesional del médico. Revista Cubana de Medicina General Integral, 21(1-2), 0-0.

Bernal Moreno, E. V., \& Botero Mejía, P. (2016). Conocimientos y prácticas sobre error médico en profesionales sanitarios, Jaibaná IPS, primer trimestre 2016.

Bernate-Ochoa, F. (2010). Imputación objetiva y responsabilidad penal médica. Editorial de la Universidad del Rosario.

Dewees, D. N., Trebilcock, M. J., \& Coyte, P. C. (1991). The medical malpractice crisis: A comparative empirical perspective. Law \& Contemp. Probs., 54, 217. https://doi.org/10.2307/1191860

Franco, A. (2006). Iatrogenia en cirugía?' Cómo evitarla? Revista Colombiana de Cirugía, 21(1), 15-22.

Gaitán, H. (2008). Los eventos adversos en la atención en salud. Revista colombiana de Obstetricia y Ginecología, 59(4), 270-272.

Guzmán, F., Franco, E., \& Morales, A. R. (1996). Negligencia en medicina. Acta Med Col, 21, 87-92.

Guzmán, F., Franco, E., Morales, M. C., \& Mendoza, J. (1994). El acto médico: Implicaciones éticas y legales. Acta médica colombiana, 19(3), 139-149.

Guzmán Mora, F. (2018). Criterios para definir la responsabilidad civil del acto médico en Colombia. Revista conamed, 6(4), 6-16.

Kunsemuller, C. (1986). Responsabilidad penal del acto médico. Revista Chilena de Derecho, 13, 259.

Lascariz Jiménez, G. (2000). Mala praxis: Responsabilidad del profesional en medicina. Medicina Legal de Costa Rica, 17(1), 9-11.

López Ordoñez, M. A., Manrique Bacca, I., \& García Torres, C. (2004). Demandas a los médicos, observaciones sobre casos. Revista colombiana de gastroenterología, 19(1), 37-43.

Marcela, T. P. L., Helena, J. S. S., \& Eduardo, M. P. L. (2011). Informes periciales por presunta responsabilidad médica en Bogotá. Revista Colombiana de Anestesiología, 39(4), 489-505. https://doi.org/10.5554/rca.v39i4.180

Millenson, M. L. (2018). Demanding medical excellence: Doctors and accountability in the information age. University of Chicago Press.

Perez, A. D. (2019). Damages and perjuries, demand, negligence as the main medical error by the surgical team: awareness surgical and praxis. jmcrr, 2(6). 
Restrepo, G. N. (2015). Tendencia de las demandas por responsabilidad medica radicadas en el cendes entre 2010 y el 2014. Facultad de Medicina. Medellín. Colombia.

Ruiz, W. (2011). La responsabilidad médica en Colombia. Criterio Jurídico, 1(4).

Schaffer, A. C., Jena, A. B., Seabury, S. A., Singh, H., Chalasani, V., \& Kachalia, A. (2017). Rates and Characteristics of Paid Malpractice Claims Among US Physicians by Specialty, 1992-2014. JAMA Internal Medicine, 177(5), 710-718. https://doi.org/10.1001/jamainternmed.2017.0311

Silversides, A. (2008). Fault/no fault: Bearing the brunt of medical mishaps. CMAJ: Canadian Medical Association Journal = Journal de l'Association Medicale Canadienne, 179(4), 309-311. https://doi.org/10.1503/cmaj.081020

Smith, C. M. (2005). Origin and uses of primum non nocere-Above all, do no harm! The Journal of Clinical Pharmacology, 45(4), 371-377. https://doi.org/10.1177/0091270004273680

Studdert, D. M., Brennan, T. A., \& Thomas, E. J. (1999). Beyond dead reckoning: Measures of medical injury burden, malpractice litigation, and alternative compensation models from Utah and Colorado. Ind. L. Rev., 33, 1643.

Tempelaar, A. F. (1997). The Problem Doctor as a Iatrogenic Factor: Risks, Errors, Malfunctioning. Problem doctors: A conspiracy of silence, 31.

Tingle, J. (2016). Managing clinical negligence litigation and costs in the NHS. British Journal of Nursing (Mark Allen Publishing), 25(21), 1218-1219. https://doi.org/10.12968/bjon.2016.25.21.1218

Vera Carrasco, O. (2013). Aspectos éticos y legales en el acto médico. Revista Médica La Paz, 19(2), 73-82.

Villota, A. I. R. (2009). Del error a la mala práctica médica, análisis de una casuística en Santiago de Cali 2006-2008. Colombia Forense, 1(1), 18-22.

\section{Copyrights}

Copyright for this article is retained by the author(s), with first publication rights granted to the journal.

This is an open-access article distributed under the terms and conditions of the Creative Commons Attribution license (http://creativecommons.org/licenses/by/4.0/). 